This is an electronic reprint of the original article. This reprint may differ from the original in pagination and typographic detail.

Please cite the original version: Tuohimaa, H. ; Rajalahti, E. ; Makkonen, A. ; Ranta L. ; Lemström, U. \& Peippo, A. (2014) Local Pilots, Virtual Tools. Experiments of Health Promotive and Inclusive Services in Different Settings in the Western Uusimaa Region. Communications in Computer and Information Science 450. In Saranto, K., Castrén, M., Kuusela, T., Hyrynsalmi, S. and Ojala S. (eds.) Safe and Secure Cities. $5^{\text {th }}$ International Conference on Well-Being in the Information Society WIS 2014 Turku, Finland, August 18-20, 2014, Proceedings.

DOI: 10.1007/978-3-319-10211-5_22

URL: https://link.springer.com/chapter/10.1007/978-3-319-10211-5_22 


\title{
Local Pilots, Virtual Tools. Experiments of Health Promotive and Inclusive Services in Different Settings in the Western Uusimaa Region.
}

Tuohimaa Hanna; Rajalahti Elina; Makkonen Anne; Ranta Liisa; Lemström Ulla; Peippo Aila

Laurea University of Applied Sciences, Lohja, Finland

Communications in Computer and Information Science 450. Saranto, K., Castrén, M., Kuusela, T., Hyrynsalmi, S. and Ojala S. (eds.) Safe and Secure Cities. $5^{\text {th }}$ international Conference on WellBeing in the Information Society WIS 2014 Turku, Finland, August 18-20, 2014, Proceedings.

The final publication is available at Springer via

http://dx.doi.org/10.1007/978-3-319-10211-5_22

http://link.springer.com/chapter/10.1007/978-3-319-10211-5_22

\begin{abstract}
In this paper we want to present five concepts for wellbeing related services and activities that have been piloted in the Western Uusimaa region as examples of ways of bringing health and wellbeing to different settings and different user groups. The pilots have been conducted for children in the kindergarten and secondary school, for adults in the health centre and for the unemployed in a variety of every day settings. We also want to present how local experiments can be put into wider use by virtual means and present the concept of the virtual wellbeing backpack family. The paper is based on work done in Laurea University of Applied Sciences (Laurea UAS) in a subproject of a cross regional project Pumppu funded by the European Regional Fund during 2011-2014.
\end{abstract}

\section{Introduction}

Sustainable living environments meet the needs of the present without compromising the ability of future generations to meet their own needs, as the Brundtland's Comission stated in their report [1]. The needs of the present and the needs of the future require different things of the living environment, with environmental sustainability more concerned with the needs of the future while social, political and economic sustainability more concerned with the needs of the present [2]. To fulfill the Brundtland's Comission's definition of sustainable development, all the perspectives are needed.

In this article, we are discussing the social sustainaibility prespective of sustainable living environments especially from the perspective of the ability of the living environment to foster health and enhance healthy living. Health is defined by the World Health Organization as "a state of complete physical, mental and social well-being and not merely the absence of disease or infirmity" [3] and health promotion as "the process of enabling people to increase control over their health and its determinants, and thereby improve their health" [4]. We share this understanding of health as a holistic concept taking into consideration both physical aspects as well as mental and social aspects. Following Antonovsky's salutogenic model [5] we see health as 
a continuum where both improvement and deterioration are always possible. We acknowledge that health promotion is not merely disease prevention and that we need to see people as they are, complex living beings with certain risks as well as assets in their life making it either a bit easier or more difficult to feel well and be happy. Although we also acknowledge the role of governments in tackling poverty, unemployment and other social determinants of health, in this paper we want to focus on the role of services in supporting wellbeing and enabling movement towards health.

The paper is based on work done in Laurea University of Applied Sciences (Laurea UAS) in a subproject of a cross regional project Pumppu funded by the European Regional Fund during 2011-2014 (A31860). The project partners developed wellbeing services in a citizen centric manner with service providers from both the public, private and the third sector in four regions in southern Finland. All the subprojects had their different focuses (person centred planning, service structure development, technology usage and service vouchers). In our subproject our focus has been on developing services and activities for health promotion and for enhancing inclusion in society in the Western Uusimaa region. The uniting theme in all the subprojects was citizen centrism and seamlessness of care and shared workshops and benchmarking visits were organized on these themes.

In the subproject of Laurea UAS, our main interest has been in finding ways to motivate and empower the individual in his/her life for actively pursuing health related goals through developing better services and supportive activities and enhancing the health literacy skills. In our vision health promotive services are seamlessly connected and easy to access with personal health goals as the starting point and information and support available throughout the personally tailored service path. Health literacy is seen not as merely basic literacy skills but also as an interactive process of participating in changing circumstances and the critical ability to evaluate information and gain greater control of one's life [6].

The settings approach of health promotion focuses on transforming the places or social contexts in which people engage in their daily activities into supportive, health promotive environments [7]. In the project, we wanted to take health issues to the everyday settings of the residents in the area, to kindergartens and schools for example. We wanted to enhance the collaboration of different service providers and other actors in the region in matters related to wellbeing. At the same time we also wanted to define the role of the UAS as a health promoter in the region. Laurea UAS works according to the Learning by Developing pedagogic model [8] where students work in projects in close collaboration with local partners conducting real life research, development and innovation (R\&D\&I) tasks. The tasks offer students authentic working life experiences and bring about learning opportunities for all the parties involved. At the same time the region and its residents benefit of the end results, in this case of the new services.

In the project, we have taken a wide definition of wellbeing services. Our main goal has been to find ways to support wellbeing and promote health in the salutogenic sense [5], with a holistic approach to health and wellbeing. The human being is seen as an empowered, functioning individual, involved in diverse social relationships. We have not been interested in services in the sense of having a service provider delivering services for the paying customer in the market. Instead, we have been interested in developing all kinds of activities that may have a positive effect on the individual taking part in them.

As we live in an information society where information technology is widely in use both in the organizations offering services as well as by the residents using the services, we also wanted to consider using technology as a tool for health promotion. Although the service pilots presented here are based on face-to-face interaction, also the possibilities of technology have been examined. 


\section{Pilots for Health Promotion and Social Inclusion in Different Settings}

In this paper we want to present wellbeing service concepts that have been piloted in the region during the project as examples of ways of bringing health and wellbeing to different settings and different user groups to promote healthier living environments and enhance the wellbeing of the residents in the region. An overview of the pilots is presented in Table 1. We also want to present how local experiments can be put into wider use by virtual means and present the concept of the virtual wellbeing backpack family.

Table 1. Short description of the pilots

\begin{tabular}{|c|c|c|c|c|c|}
\hline Pilot & Target group & Setting & Focus & $\begin{array}{l}\text { Feedback } \\
\text { method }\end{array}$ & Results \\
\hline $\begin{array}{l}\text { The Early } \\
\text { support for } \\
\text { mental } \\
\text { health }\end{array}$ & $\begin{array}{l}13 \text { to } 16 \text { year old } \\
\text { pupils }\end{array}$ & $\begin{array}{l}\text { Secondary } \\
\text { school }\end{array}$ & $\begin{array}{l}\text { Low threshold } \\
\text { services for } \\
\text { mental } \\
\text { wellbeing }\end{array}$ & $\begin{array}{l}\text { Questionnaire: } \\
118 \text { pupils } \\
\text { Interview: } \\
3 \text { staff members } \\
\text { and } 3 \text { nursing } \\
\text { students }\end{array}$ & $\begin{array}{l}53 \% \text { saw the } \\
\text { need to } \\
\text { continue the } \\
\text { pilot } \\
\text { The pilot was } \\
\text { seen as an } \\
\text { important } \\
\text { proactive, low } \\
\text { threshold } \\
\text { service in } \\
\text { addition to the } \\
\text { official } \\
\text { counceling } \\
\text { services }\end{array}$ \\
\hline $\begin{array}{l}\text { Learning } \\
\text { sessions }\end{array}$ & $\begin{array}{l}15 \text { year old } \\
\text { pupils }\end{array}$ & $\begin{array}{l}\text { Secondary } \\
\text { school }\end{array}$ & $\begin{array}{l}\text { Health literacy } \\
\text { skills and } \\
\text { understanding } \\
\text { of national } \\
\text { diseases }\end{array}$ & $\begin{array}{l}\text { Questionnaire: } \\
71 \text { pupils }\end{array}$ & $\begin{array}{l}89 \% \text { gained } \\
\text { new } \\
\text { knowledge } \\
68 \% \text { started } \\
\text { thinking about } \\
\text { their health } \\
33 \% \text { planned } \\
\text { to change their } \\
\text { lifestyle }\end{array}$ \\
\hline
\end{tabular}




\begin{tabular}{|c|c|c|c|c|c|}
\hline $\begin{array}{l}\text { Good for the } \\
\text { Child }\end{array}$ & $\begin{array}{l}3 \text { to } 6 \text { year old } \\
\text { children }\end{array}$ & Kindergarten & $\begin{array}{l}\text { Health literacy } \\
\text { skills and } \\
\text { understanding } \\
\text { of healthy } \\
\text { nutrition and } \\
\text { sleep for the } \\
\text { children as well } \\
\text { as the parents }\end{array}$ & $\begin{array}{l}\text { Questionnaire: } \\
17 \text { parents }\end{array}$ & $\begin{array}{l}100 \% \text { saw } \\
\text { health } \\
\text { promotion as } \\
\text { appropriate in } \\
\text { the } \\
\text { kindergarten } \\
\text { setting } \\
47 \% \text { saw an } \\
\text { effect of the } \\
\text { nutrition } \\
\text { theme at } \\
\text { home }\end{array}$ \\
\hline \begin{tabular}{|l} 
Pop up \\
counseling \\
point
\end{tabular} & The unemployed & $\begin{array}{l}\text { Different } \\
\text { everyday } \\
\text { settings: } \\
\text { shopping } \\
\text { centres, events, } \\
\text { health centres }\end{array}$ & $\begin{array}{l}\text { Low threshold } \\
\text { services and } \\
\text { counseling on } \\
\text { available } \\
\text { services for } \\
\text { those that are } \\
\text { difficult to reach }\end{array}$ & $\begin{array}{l}\text { Questionnaire: } \\
23 \text { visitors at the } \\
\text { counseling point }\end{array}$ & $\begin{array}{l}91 \% \text { got good } \\
\text { counseling } \\
59 \% \text { agreed or } \\
\text { mostly agreed } \\
\text { that the web } \\
\text { page } \\
\text { responded } \\
\text { well to their } \\
\text { specific needs }\end{array}$ \\
\hline $\begin{array}{l}\text { Self care } \\
\text { stations }\end{array}$ & $\begin{array}{l}\text { The adult } \\
\text { population in } \\
\text { two } \\
\text { municipalities }\end{array}$ & Health centres & $\begin{array}{l}\text { Support for self } \\
\text { care }\end{array}$ & $\begin{array}{l}\text { Questionnaire: } \\
21 \text { users of the } \\
\text { self care station }\end{array}$ & $\begin{array}{l}95 \% \text { saw the } \\
\text { station as } \\
\text { important in } \\
\text { their self care } \\
71 \% \text { got } \\
\text { answers to } \\
\text { specific } \\
\text { questions on } \\
\text { their mind }\end{array}$ \\
\hline
\end{tabular}

The Early support for mental health concept was designed to offer easy access discussion support for the pupils (aged 13 to 16) in secondary school. The concept was piloted in one school for two 10 week phases with two nurse students having an open practice during the breaks where the pupils could come and talk about every day issues. The nurse students also visited classes during lessons. The hypothesis was that low threshold services would make it easier for the pupils to discuss about matters close to heart and make it easier to seek help. The pilot was evaluated in two phases, first with a questionnaire to eight graders (aged 14 to $15 n=118$ ) in the middle of the first pilot phase [9] and then with focus group interviews to the staff and the nurse students after the second pilot phase [10]. As the feedback was gathered after five weeks of piloting, only one in five of the eight graders had visited the open practice, mostly talking about life in general. 53\% of the students thought that it would be important to have the open practice in the school also in 
the future. Two thirds considered it good to have an adult to talk with. Only seven pupils had something negative to say, e.g. that not everybody wants to talk about his/her life. In the interviews for the staff the open practice was considered as an important unofficial place for discussion in addition to the official counseling services. In the short time perspective of the pilot phase it is not possible to evaluate the effects of the pilot on a longer time scale but the feedback acknowledges the benefits of having easy access services available.

In the Learning sessions pilot the goal was to increase the health literacy skills of teenagers through the use of participative methods in the secondary school setting. The nursing students planned and implemented training sessions in four secondary schools for 15 -year-old pupils. The sessions included subjects related to Finnish national diseases (such as coronary heart disease, diabetes and cancer) and first-aid. The hypothesis was that pupils would benefit from interactional sessions and the learning methods would make health related subjects easy to understand. For example, one group drew the human figure on the floor of the gym hall. They marked four points on this figure; head, heart, limbs and guts. In each point nursing students discussed with the pupils, what it means to the specific part of the body if you are smoking, drinking alcohol, eating unhealthy food or not exercising. Pupils also had crossword-puzzles, where they could find the right answers at each point. After the sessions feedback was gathered of the pupils $(n=71)$. The results showed that the pupils benefited from the training sessions, gaining a deeper understanding about the diseases ( 89 percent) and first-aid skills (92 percent). 33 percent of the pupils claimed that they would change their lifestyle for the better. Of the rest many pointed out in the open comments that they already lead a healthy life and did not see a need to make any changes. As the results of the pilot were promising about the participative methods in teaching health related subjects, the idea was further developed into the gamification of the subject matter. As a result, a small health promotive internet based game has been constructed in the project.

The Good for the Child -concept was designed for the kindergarten to bring health related subjects to the everyday activities of children of 3 to 6 years old and their families. The hypothesis was that through the children it would be possible to also reach the parents and influence the health behavior of the whole family. In the first pilot phase two students gathered materials and tested activities related to healthy nutrition and sleep. Besides activities for the children also activities for the parents and the whole family were designed. The activities included e.g. tasting foods, painting about dreams and sewing plush toys out of old pyjamas. For the parents, discussion evenings were organized. Feedback was gathered from the parents $(n=17)$ by a questionnaire. In the feedback fifteen parents considered the pilot as a very good or a rather good experience and all saw health promotive activities as suitable for kindergartens. The most discussed activity at home was the sewing of the plush toys.

In the feedback, two thirds of the children had talked about health related issues at home with regard to nutrition but less than one third with regard to sleep. $47 \%$ of the parents thought that the activities related to nutrition had had some kind of an effect at home, only one in five saw effects of the activities related to sleep. For example, the children had learned to eat lettuce and the families had paid more attention to healthy food. Although the effects on sleep were more uncommon, some children had become more aware of the benefits of going to bed early at night. The results showed that even a small scale piloting phase can have an effect at home, however the results depend on the subject matter. For instance, although the sewing of the plush toy was discussed at home, it did not always result in discussing sleep related matters.

In The Good for the Child -pilot the students gathered all the material and instructions that they had used in the pilot phase in a briefcase to be used later on by other students in other 
kindergartens. The instructions were also left at the kindergartens for further use. In the following pilot phases, new materials were developed for other themes such as exercise. As we wanted to share the material with as many kindergartens as possible, we decided to make a virtual backpack of the materials. In fact, the idea escalated into a whole family of virtual backpacks for different purposes and case groups available online for all interested parties.

One of the concepts that had been developed earlier in the project was further developed prior to piloting to include a virtual backpack from the start. The idea was to take a counseling desk to places where unemployed people would be, to put up a Pop up counseling point for contacting the unemployed. The hypothesis was that it would be easier to reach the unemployed if contacting them in places that they visit rather than trying to get them to come to some service point. Through the virtual backpack, the counselor would have all the information that she/he needs on a tablet, instead of separate leaflets. At the same time the material would be available online for the unemployed themselves, too, as well as other service providers. The material included e.g. information about the rights of the unemployed, paths towards employment, wellbeing related information and tips for low budget activities in the region.

The Pop up counseling point was piloted in several settings in the region: at the shopping centre, hospital, health centre and at a career event for the youth. Feedback was gathered from the people who were contacted at the counseling point $(n=23) .47 \%$ of the ones giving feedback were currently not in the labour force (they were e.g. unemployed or on unemployment pension), 30\% had a job and 22\% chose the alternative "other" (not specified further). In the feedback, 91\% agreed or mostly agreed that they got good counseling at the counseling point. $59 \%$ agreed or mostly agreed with the statement that the web page used for counseling responded well to their specific needs and $57 \%$ with the statement that the web page offered new information for taking care of their health. This feedback shows that low threshold guidance services are appreciated although the subject matters still need some tuning.

Although in the project, we wanted to take health related issues to different every day settings, we did not want to undermine the role of the health center in promoting health, either. In fact, a local public health care provider was one of our key partners in the project. One of the pilots in the project was developing the Self care stations for two local health centres. At the Self care stations, the residents have the opportunity to e.g. measure their blood pressure levels and calculate their body mass index independently, yet having help available if necessary. There are also a variety of leaflets and other materials available, both related to health as well as related to the services and activities available in the region. The hypothesis was that the equipment and information available at the Self care stations would support self care and encourage personal activity in health related matters. The residents and the health centre staff have had the opportunity to participate in the development of the Self care stations to better respond to their needs.

User feedback of the Self care stations was gathered after the opening of the stations through a questionnaire and a return box at both of the Self care stations (21 respondents). Most of the users used the Self care station to measure their blood pressure levels. The users generally thought that the station had enough materials and leaflets. Some suggestions for further development were made e.g. in relation to also measuring the sugar levels or having better equipment for measuring the height. The results showed that $95 \%$ of the Self care station users giving feedback saw the station as important in their self care. $71 \%$ got answers to specific questions on their mind. The Self care stations clearly benefitted the users.

Also materials related to self care have been put in a virtual wellbeing backpack. The materials have already been utilized in the next Self care station piloting in the spring of 2014 in another health centre. When having a computer at the Self care station, the materials of the virtual 
backpack can be viewed by the clients at the station. The backpack can also be utilized by service providers interested in developing their own Self care stations. The same way as the other backpacks this backpack could be further developed later on, after the project, by new student groups to include new materials and viewpoints. The backpack can include both general material as well as region specific instructions.

\section{Conclusion}

The pilots presented here offer examples of new ways of grasping health and wellbeing related issues in different settings and for different case groups. The feedback results show that even a small scale pilot can have a positive effect on the individual or the whole family. Potential for long term development work to analyze long term effects clearly exist. Through consecutive piloting rounds the materials and tools can be tuned to offer the best outcomes.

The pilot phases have been conducted by nursing students as part of their studies, in collaboration with the staff in the schools and kindergartens and other actors in the region. Through the virtual backpack family the materials can be made available for all interested parties and the concepts developed further for different locations. The experiments may also lead to new innovations, as with the health promotive game that was developed for the youth after the Learning sessions pilot.

Some of the pilots can be continued as such by the service providers in the region. For instance, the activity sessions for the kindergartens can be carried on by the staff as part of the daily activities. However, the pilots also showed the role that the nursing students can have as health promoters in the region. The nursing studies include training periods in kindergartens, schools and other facilities besides the health centres and hospitals. With the developed materials every training period can be seen as an opportunity for health promotion. With the project based Learning by Developing pedagogic model other study units can also be harnessed to developing and piloting new kinds of services, crossing sector lines and seeking new forms of collaboration with partners in the region.

\section{References}

1. United Nations: Report of the World Commission on Environment and Development. Our Common Future. (1987).

2. Satterthwaite, D.: Sustainable Cities or Cities that Contribute to Sustainable Development? Urban Studies 34(10): 1667-1691. (1997)

3. WHO: Preamble to the Constitution of the World Health Organization as adopted by the International Health Conference, New York, 19-22 June, 1946; signed on 22 July 1946 by the representatives of 61 States (Official Records of the World Health Organization, no. 2, p. 100) and entered into force on 7 April 1948. (1948)

4. WHO: Ottawa Charter for Health Promotion. WHO, Geneva. (1986)

5. Antonovsky, A.: The Salutogenic Model as a Theory to Guide Health Promotion. Health Promotion International 11(1): 11-18. (1996)

6. Nutbeam, D.: Health Literacy as a Public Health Goal: a Challenge for Contemporary Health Education and Communication Strategies into the $21^{\text {st }}$ Century. Health Promotion International 15(3): 259-267.

7. WHO: Health Promotion Glossary. WHO, Geneva. (1998)

8. Raij, K.: Learning by Developing. Laurea Publications A-58. Laurea University of Applied Sciences. (2007)

9. Tarilo, C.: Kyselylomake sairaanhoitajaopiskelijoiden vastaanottotoiminnasta 8- luokkalaisille. Kyselylomakkeiden sisällönanalyysi. Working paper, unpublished. (2013) 
10. Mattila, P.: Sairaanhoitajan ennakoiva toiminta yläkoulussa. Thesis. Laurea University of Applied Sciences, Vantaa. (2014)

The websites of the project:

www.laurea.fi/pumppu (The Laurea UAS subproject webpage in Finnish)

www.laurea.fi/en/cofi/projects/Pages/Pumppu.aspx (The Laurea UAS subproject webpage in English)

www.laurea.fi/hyvinvointireppu (The Laurea UAS subproject Wellbeing backpack pages in Finnish)

pumppu-hanke.blogspot.fi/ (the webpage of the whole Pumppu project in Finnish) 